\title{
FILSAFAT PANCASILA DALAM PENDIDIKAN DI INDONESIA MENUJU BANGSA BERKARAKTER
}

\author{
Yoga Putra Semadi \\ Pendidikan Bahasa dan Sastra Indonesia, Universitas Pendidikan Ganesha Singaraja, \\ Indonesia \\ E-mail: yoga_semadi@ymail.com
}

\begin{abstract}
Abstrak
Pancasila adalah dasar dan ideologi bangsa Indonesia yang mempunyai fungsi dalam kehidupan bangsa dan negara Indonesia. Filsafat adalah berpikir secara mendalam dan sungguh-sungguh untuk mencari kebenaran. Filsafat pendidikan adalah pemikiran yang mendalam tentang pendidikan berdasarkan filsafat. Apabila kita hubungkan fungsi Pancasila dengan sistem pendidikan ditinjau dari filsafat pendidikan, maka Pancasila merupakan pandangan hidup bangsa yang menjiwai dalam kehidupan sehari-hari. Karena itu, sistem pendidikan nasional Indonesia wajar apabila dijiwai, didasari dan mencerminkan identitas Pancasila. Pancasila adalah falsafah yang merupakan pedoman berperilaku bagi bangsa Indonesia yang sesuai dengan kultur bangsa Indonesia. Pendidikan karakter memang seharusnya diambil dari nilai-nilai yang terkandung dalam Pancasila. Agar tercipta manusia Indonesia yang cerdas, berperilaku baik, mampu hidup secara individu dan sosial, memenuhi hak dan kewajiban sebagai warga negara yang baik serta beriman dan bertaqwa kepada Tuhan Yang Maha Esa. Semuanya telah mencakup filsafat pendidikan Pancasila yang mempunyai ciri, yaitu integral, etis, dan reigius.
\end{abstract}

Kata Kunci: Filsafat Pancasila; Pendidikan Indonesia; Bangsa Berkarakter

\begin{abstract}
Pancasila is the basis and ideology of the Indonesian nation which has a function in the life of the Indonesian nation and country. Philosophy is to think deeply and sincerely to find the truth. Educational philosophy is a deep thought about education based on philosophy. If we connect the function of the Pancasila with the education system in terms of the philosophy of education, the Pancasila is the nation's life view that animates in everyday life. Therefore, Indonesia's national education system is reasonable if it is imbued, based on and reflects the identity of Pancasila. Pancasila is a philosophy which is a code of conduct for the Indonesian people in accordance with the culture of the Indonesian people. Character education should be taken from the values contained in Pancasila. In order to create intelligent Indonesian people who behave well, be able to live individually and socially, fulfill their rights and obligations as good citizens and have faith and devotion to God Almighty. Everything has included the philosophy of Pancasila education which has characteristics, namely integral, ethical and religious.
\end{abstract}

Keyword: Pancasila Philosophy; Indonesian Education; Nation with Character

\section{Pendahuluan}

Pancasila merupakan dasar pandangan hidup rakyat Indonesia yang di dalamnya memuat lima dasar yang isinya merupakan jati diri bangsa Indonesia. Sila-sila dalam Pancasila menggambarkan tentang pedoman hidup berbangsa dan bernegara bagi manusia Indonesia seluruhnya dan seutuhnya. Masuknya Pancasila sebagai suatu ideologi dan falsafah bangsa Indonesia tak lepas pula dari peran Bung Karno. Menurut Sutrisno (2006), "Pancasila adalah suatu philosofiche grounfslag atau Weltanschauung yang diusulkan Bung Karno di depan sidang BPUPKI 1 Juni 1945 sebagai dasar negara Indonesia yang kemudian merdeka." Suatu masyarakat atau bangsa menjadikan filsafat sebagai suatu pandangan hidup, yaitu merupakan asas dan pedoman yang melandasi semua aspek hidup dan kehidupan bangsa tersebut, tanpa terkecuali aspek pendidikan. 
Filsafat yang dikembangkan harus berdasarkan filsafat yang dianut oleh suatu bangsa, sedangkan pendidikan merupakan suatu cara atau mekanisme dalam menanamkan dan mewariskan nilai-nilai filsafat tersebut. Pendidikan sebagai suatu lembaga yang berfungsi menanamkan dan mewariskan sistem norma tingkah laku perbuatan yang didasarkan kepada dasar-dasar filsafat yang dijunjung oleh lembaga pendidikan dan pendidik dalam suatu masyarakat. Untuk menjamin supaya pendidikan dan prosesnya efektif, maka dibutuhkan landasan-landasan filosofis dan landasan ilmiah sebagai asas normatif dan pedoman pelaksanaan pembinaan (Noor: 1988).

Sebagai sebuah falsafah dan sebuah ideologi bagi bangsa Indonesia, Pancasila adalah dasar dari pelaksanaan segala aspek kehidupan bagi bangsa Indonesia. Salah satunya adalah dalam bidang pendidikan. Dalam UU No.12 Tahun 2012 Pasal 1 tentang Pendidikan Tinggi disebutkan bahwa "Pendidikan adalah usaha sadar dan terencana untuk mewujudkan suasana belajar dan proses pembelajaran agar peserta didik secara aktif mengembangkan potensi dirinya untuk memiliki kekuatan spiritual keagamaan, pengendalian diri, kepribadian, kecerdasan, akhlak mulia, serta keterampilan yang diperlukan dirinya, masyarakat, bangsa, dan negara. Dari Undang-undang di atas dapat dimaknai bahwa pendidikan di Indonesia adalah sebuah proses pembelajaran yang berupaya untuk tujuan pengembangan potensi diri dan karakter bagi peserta didik. Disini Sila-sila Pancasila mencerminkan bagaimana seharusnya pendidikan harus dihayati dan diamalkan menurut sila-sila dalam Pancasila.

Pengertian karakter menurut Pusat Bahasa Depdiknas adalah "bawaan, hati, jiwa, kepribadian, budi pekerti, perilaku, personalitas, sifat, tabiat, temperamen, watak". Adapun berkarakter adalah berkepribadian, berperilaku, bersifat, bertabiat, dan berwatak". Menurut Musfiroh (2008), karakter mengacu kepada serangkaian sikap (attitudes), perilaku (behaviors), motivasi (motivations), dan keterampilan (skills). Karakter berasal dari bahasa Yunani yang berarti "to mark" atau menandai dan memfokuskan bagaimana mengaplikasikan nilai kebaikan dalam bentuk tindakan atau tingkah laku, sehingga orang yang tidak jujur, kejam, rakus dan perilaku jelek lainnya dikatakan orang berkarakter jelek. Sebaliknya, orang yang perilakunya sesuai dengan kaidah moral disebut dengan berkarakter mulia.

Pancasila sebagai sistem filsafat bisa dilihat dari pendekatan ontologis, epistemologis, maupun aksiologis. Diktat "Filsafat Pancasila" (Danumihardja, 2011) menyebutkan secara ontologis berdasarkan pada pemikiran tentang negara, bangsa, masyarakat, dan manusia. Secara epistemologis berdasarkan sebagai suatu pengetahuan intern struktur logis dan konsisten implementasinya. Secara aksiologis bedasarkan pada yang terkandung di dalamnya, hierarki dan struktur nilai, di dalamnya konsep etika yang terkandung. Dasar ontologis Pancasila sebagai sistem filsafat bisa diinterpretasikan bahwa adanya negara perlu dukungan warga negara. Kualitas negara sangat bergantung pada kualitas warga negara. Kualitas warga negara sangat erat berkaitan dengan pendidikan. Hubungan ini juga menjadi timbal-balik karena landasan pendidikan haruslah mengacu pada landasan negara. Esensi landasan negara harus benarbenar memperkuat landasan pendidikan untuk mencapai tujuan bersama adanya keserasian hubungan antara negara dengan warga negara.

\section{Metode}

Metode yang digunakan untuk menyusun artikel ini adalah study kepustakaan. Study kepustakaan, yaitu menelaah sumber-sumber, baik itu buku, artikel, referensi-referensi yang berkaitan dengan filsafat Pancasila dalam pendidikan di Indonesia untuk membentuk bangsa yang berkarakter. Telaah penelitian sejenis juga dilakukan agar mendapat simpulan yang valid dan akurat.

\section{Hasil dan Pembahasan}

\section{Filsafat Pancasila \\ Hakikat Filsafat Pancasila}

Filsafat berasal dari kata Philosophy yang secara epistimologis berasal dari philos atau phileinyang yang artinya cinta dan shopia yang berarti hikmat atau kebijaksanaan. Secara epistimologis bermakna cinta kepada hikmat atau kebijaksanaan (wisdom) (Sutrisno, 2006). Pancasila juga merupakan sebuah filsafat karena pancasila merupakan acuan intelektual kognitif bagi cara berpikir bangsa, yang dalam usaha-usaha keilmuan dapat terbangun ke dalam sistem 
filsafat yang kredibel. Menurut Abdulgani (dalam Ruyadi, 2003), Pancasila merupakan filsafat negara yang lahir sebagai collective ideologie (cita-cita bersama) dari seluruh bangsa Indonesia. Pancasila merupakan hasil perenungan jiwa yang dalam, yang kemudian dituangkan dalam suatu "sistem" yang tepat. Sedangkan Notonagoro (dalam Ruyadi, 2003) menyatakan bahwa Filsafat Pancasila memberikan pengetahuan dan pengertian ilmiah, yaitu tentang hakikat dari Pancasila.

Pancasila sebagai suatu sistem filsafat, memiliki dasar ontologis, dasar epistemologis dan dasar aksiologis tersendiri yang membedakannya dengan sistem filsafat lain. Secara ontologis, kajian Pancasila sebagai filsafat dimaksudkan sebagai upaya untuk mengetahui hakikat dasar dari sila-sila Pancasila. Notonagoro (dalam Ganeswara, 2007) menyatakan bahwa hakikat dasar ontologis Pancasila adalah manusia, sebab manusia merupakan subjek hukum pokok dari Pancasila. Selanjutnya, hakikat manusia itu adalah semua kompleksitas makhluk hidup, baik sebagai makhluk individu maupun sebagai makhluk sosial. Secara lebih lanjut, hal ini bisa dijelaskan bahwa yang berke-Tuhanan Yang Maha Esa, yang berkemanusiaan yang adil dan beradab, yang berpersatuan Indonesia, yang berkerakyatan yang dipimpin oleh hikmah kebijaksanaan dalam permusyawaratan/perwakilan serta yang berkeadilan sosial adalah manusia.

Kajian epistemologis filsafat Pancasila, dimaksudkan sebagai upaya untuk mencari hakikat Pancasila sebagai suatu sistem pengetahuan. Menurut Titus (dalam Kaelan, 2007) terdapat tiga persoalan mendasar dalam epistemology, yaitu: (1) tentang sumber pengetahuan manusia; (2) tentang teori kebenaran pengetahuan manusia; dan (3) tentang watak pengetahuan manusia. Tentang sumber pengetahuan Pancasila, sebagaimana diketahui bahwa Pancasila digali dari nilai-nilai luhur bangsa Indonesia sendiri serta dirumuskan secara bersama-sama oleh "The Founding Fathers" kita. Jadi bangsa Indonesia merupakan Kausa Materialis-nya Pancasila. Selanjutnya, Pancasila sebagai suatu sistem pengetahuan memiliki susunan yang bersifat formal logis, baik dalam arti susunan sila-silanya maupun isi arti dari sila-silanya. Susunan sila-sila Pancasila bersifat hierarkis piramidal. Selanjutnya, sila-sila Pancasila sebagai suatu sistem filsafat juga memiliki satu kesatuan dasar aksiologinya, yaitu nilai-nilai yang terkandung dalam Pancasila pada hakikatnya juga merupakan suatu kesatuan.

\section{Prinsip-Prinsip Filsafat Pancasila}

Pancasila ditinjau dari kausal Aristoteles dapat dijelaskan sebagai berikut.

a. Kausa Materialis, maksudnya sebab yang berhubungan dengan materi/bahan, dalam hal ini Pancasila digali dari nilai-nilai sosial budaya yang ada dalam bangsa Indonesia sendiri.

b. Kausa Formalis, maksudnya sebab yang berhubungan dengan bentuknya, Pancasila yang ada dalam pembukaan UUD ' 45 memenuhi syarat formal (kebenaran formal).

c. Kausa Efisiensi, maksudnya kegiatan BPUPKI dan PPKI dalam menyusun dan merumuskan Pancasila menjadi dasar negara Indonesia merdeka.

d. Kausa Finalis, maksudnya berhubungan dengan tujuannya, tujuan diusulkannya Pancasila sebagai dasar negara Indonesia merdeka.

Inti atau esensi sila-sila Pancasila meliputi:

a. ke-Tuhanan, yaitu sebagai kausa prima;

b. kemanusiaan, yaitu makhluk individu dan makhluk sosial;

c. kesatuan, yaitu kesatuan memiliki kepribadian sendiri;

d. kerakyatan, yaitu unsur mutlak negara, harus bekerja sama dan gotong royong; dan

e. keadilan, yaitu memberikan keadilan kepada diri sendiri dan orang lain yang menjadi haknya.

\section{Nilai-Nilai Pancasila}

Nilai adalah suatu ide atau konsep tentang apa yang seseorang pikirkan merupakan hal yang penting dalam hidupnya. Nilai dapat berada di dua kawasan: kognitif dan afektif. Nilai adalah ide, bisa dikatakan konsep dan bisa dikatakan abstraksi (Simon, 1986). Nilai merupakan hal yang terkandung dalam hati nurani manusia yang lebih memberi dasar dan prinsip akhlak yang merupakan standar dari keindahan dan efisiensi atau keutuhan kata hati (potensi). Langkahlangkah awal dari "nilai" adalah seperti halnya ide manusia yang merupakan potensi pokok human being. Nilai tidaklah tampak dalam dunia pengalaman. Dia nyata dalam jiwa manusia. Dalam ungkapan lain ditegaskan oleh Simon (1986) bahwa sesungguhnya yang dimaksud dengan nilai adalah jawaban yang jujur tapi benar dari pertanyaan "what you are really, really, really, want."

Studi tentang nilai termasuk dalam ruang lingkup estetika dan etika. Estetika cenderung kepada studi dan justifikasi yang menyangkut tentang manusia memikirkan keindahan, atau apa 
yang mereka senangi. Misalnya, mempersoalkan atau menceritakan si rambut panjang, pria pemakai anting-anting, nyanyian-nyanyian bising, dan bentuk-bentuk seni lainnya. Sedangkan etika cenderung kepada studi dan justifikasi tentang aturan atau bagaimana manusia berperilaku. Ungkapan etika sering timbul dari pertanyaan-pertanyaan yang mempertentangkan antara benarsalah, baik-buruk. Pada dasarnya, studi tentang etika merupakan pelajaran tentang moral yang secara langsung merupakan pemahaman tentang apa itu benar dan salah.

Bangsa Indonesia sejak awal mendirikan negara, berkonsensus untuk memegang dan menganut Pancasila sebagai sumber inspirasi, nilai dan moral bangsa. Konsensus bahwa Pancasila sebagai anutan untuk pengembangan nilai dan moral bangsa ini secara ilmiah filosofis merupakan pemufakatan yang normatif. Secara epistemological, bangsa Indonesia punya keyakinan bahwa nilai dan moral yang terpancar dari asas Pancasila ini sebagai suatu hasil sublimasi dan kritalisasi dari sistem nilai budaya bangsa dan agama yang kesemuanya bergerak vertikal dan horizontal serta dinamis dalam kehidupan masyarakat. Selanjutnya, untuk mensinkronkan dasar filosofis-ideologi menjadi wujud jati diri bangsa yang nyata dan konsekuen secara aksiologikal bangsa dan negara Indonesia berkehendak untuk mengerti, menghayati, membudayakan dan melaksanakan Pancasila. Upaya ini dikembangkan melalui jalur keluarga, masyarakat, dan sekolah.

Refleksi filsafat yang dikembangkan oleh Notonegoro untuk menggali nilai-nilai abstrak, hakikat nilai-nilai Pancasila, ternyata kemudian dijadikan pangkal tolak pelaksanaannya yang berujud konsep pengamalan yang bersifat subjektif dan objektif. Pengamalan secara objektif adalah pengamalan di bidang kehidupan kenegaraan atau kemasyarakatan yang penjelasannya berupa suatu perangkat ketentuan hukum yang secara hierarkis berupa pasal-pasal UUD, Ketetapan MPR, Undang-undang Organik dan peraturan-peraturan pelaksanaan lainnya. Pengamalan secara subjektif adalah pengamalan yang dilakukan oleh manusia individual, baik sebagai pribadi maupun sebagai warga masyarakat ataupun sebagai pemegang kekuasaan yang penjelmaannya berupa tingkah laku dan sikap dalam hidup sehari-hari. Nilai-nilai yang bersumber dari hakikat Tuhan, manusia, satu rakyat dan adil dijabarkan menjadi konsep Etika Pancasila, bahwa hakikat manusia Indonesia adalah untuk memiliki sifat dan keadaan yang berperiKetuhanan Yang Maha Esa, berperi-Kemanusiaan, berperi-Kebangsaan, berperi-Kerakyatan, dan berperi-Keadilan Sosial.

\section{Filsafat Pancasila dalam Pendidikan di Indonesia}

Pendidikan dilakukan oleh manusia melalui kegiatan pembelajaran. Dalam praktik pendidikan yang universal banyak ditemukan beragam komunitas dari manusia yang memberikan makna yang beragam dari pendidikan. Di Indonesia, pendidikan ditekankan pada penguasaan landasan terbentuknya masyarakat meritorik, artinya memberikan waktu jam pelajaran yang luas dalam penguasaan mata pelajaran tertentu. Pendidikan berdasarkan terminologi merupakan terjemahan dari istilah Pedagogi. Istilah ini berasal dari bahasa Yunani, yaitu Paidos dan Agoo. Paidos artinya budak dan Agoo artinya membimbing. Pedagogi dapat diartikan sebagai budak yang mengantarkan anak majikan untuk belajar. (Jumali dkk, 2004) menjelaskan bahwa hakikat pendidikan adalah kegiatan yang melibatkan guru, murid, kurikulum, evaluasi, administrasi yang secara simultan memproses peserta didik menjadi lebih lebih bertambah pengetahuan, skill, dan nilai kepribadiannya dalam suatu keteraturan kalender akademik.

Filsafat pendidikan Indonesia berakar pada nilai-nilai budaya yang terkandung pada Pancasila. Nilai Pancasila tersebut harus ditanamkan pada peserta didik melalui penyelenggaraan pendidikan nasional dalam semua level dan jenis pendidikan. Ada dua pandangan yang menurut (Jumali dkk, 2004), perlu dipertimbangkan dalam menetukan landasan filosofis dalam pendidikan Indonesia. Pertama, pandangan tentang manusia Indonesia. Filosofis pendidikan nasional memandang bahwa manusia Indonesia sebagai:

a. makhluk Tuhan Yang Maha Esa dengan segala fitrahnya;

b. makhluk individu dengan segala hak dan kewajibannya;

c. makhluk sosial dengan segala tanggung jawab hidup dalam masyarakat yang pluralistik, baik dari segi lingkungan sosial budaya, lingkungan hidup, dan segi kemajuan Negara Kesatuan Republik Indonesia di tengah-tengah masyarakat global yang senantiasa berkembang dengan segala tantangannya.

Kedua, Pandangan tentang pendidikan nasional itu sendiri. Dalam pandangan filosofis pendidikan nasional dipandang sebagai pranata sosial yang selalu berinteraksi dengan kelembagaan sosial lainnya dalam masyarakat. Menurut John Dewey, filsafat pendidikan 
merupakan suatu pembentukan kemampuan dasar yang fundamental, baik yang menyangkut daya pikir (intelektual) maupun daya perasaan (emosional) menuju ke arah tabiat manusia, maka filsafat juga diartikan sebagai teori umum pendidikan. Brubachen berpendapat bahwa filsafat pendidikan adalah seperti menaruh sebuah kereta di depan seekor kuda dan filsafat dipandang sebagai bunga, bukan sebagai akar tunggal pendidikan. Filsafat pendidikan itu berdiri secara bebas dengan memperoleh keuntungan karena memiliki kaitan dengan filsafat umum, meskipun kaitan tersebut tidak penting, yang terjadi adalah suatu keterpaduan antara pandangan filosofi dengan filsafat pendidikan karena filsafat sering diartikan sebagai teori pendidikan secara umum (Arifin, 1993).

Pendidikan merupakan usaha sadar yang sengaja dan terencana untuk membantu perkembangan potensi dan kemampuan anak agar bermanfaat bagi kepentingan hidupnya sebagai individu dan sebagai warga masyarakat. Pendidikan dipandang mempunyai peranan yang besar dalam mencapai keberhasilan dalam perkembangan anak. Dalam sejarah pendidikan, dapat dijumpai berbagai pandangan atau teori mengenai perkembangan manusia dan hasil pendidikan, yaitu sebagai berikut.

a. Empirisme, bahwa hasil pendidikan dan perkembangan itu bergantung pada pengalaman yang diperoleh anak didik selama hidpnya. Pengalaman itu diperolehnya di luar dirinya berdasarkan perangsang yang tersedia baginya, John Locke berpendapat bahwa anak yang dilahirkan di dunia ini bagaikan kertas kosong atau sebagai meja berlapis lilin (tabula rasa) yang belum ada tulisan diatasnya.

b. Nativisme, teori yang dianut oleh Schopenhauer yang berpendapat bahwa bayi lahir dengan pembawan baik dan pembawan yang buruk. Dalam hubungannya dengan pendidikan, ia berpendapat bahwa hasil akhir pendidikan dan perkembangan itu ditentukan oleh pembawaan yang sudah diperolehnya sejak lahir. Aliran ini berpendapat bahwa pendidikan tidak dapat menghasilkan tujuan yang diharapkan berhubungan dengan perkembangan anak didik. Dengan kata lain, aliran nativisme merupakan aliran Pesimisme dalam pendidikan, berhasil tidaknya perkembangan anak tergantung pada tinggi rendahnya dan jenis pembawaan yang dimilikinya.

c. Naturalisme, dipelopori oleh J.J Rousseau, ia berpendapat bahwa semua anak yang baru lahir mempunyai pembawaan yang baik, tidak seorang anak pun lahir dengan pembawaan buruk. Aliran ini berpendapat bahwa pendidik hanya wajib membiarkan pertumbuhan anak didik saja dengan sendirinya, diserahkan saja selanjutnya kepada alam (negativisme). Pendidikan tidak diperlukan, yang dilaksanakan adalah menyerahkan anak didik ke alam, agar pembawaan yang baik tidak rusak oleh tangan manusia melalui proses pendidikan.

d. Konvergensi, dipelopori oleh William Stern, yang berpendapat bahwa anak dilahirkan dengan pembawaan baik dan buruk. Hasil pendidikan itu bergantung dari pembawaan dan lingkungan. Pendidikan diartikan sebagai penolong yang diberikan kepada lingkugan anak didik untuk mengembangkan pembawaan yang baik dan mencegah berkembangnya pembawan yang buruk. Dalam kehidupan suatu bangsa, pendidikan mempunyai peranan yang amat penting untuk menjamin perkembangan dan kelangsungan kehidupan bangsa. Indonesia adalah negara yang berdasarkan pada Pancasila dan Undang-Undang dasar 1945 yang di dalamnya diatur bahwa pendidikan diusahakan dan diselenggarakan oleh pemerintah sebagai satu sistem pengajaran nasional.

Aristoteles mengatakan, bahwa tujuan pendidikan sama dengan tujuan didirikannya suatu negara (Rapar, 1988). Demikian juga dengan Indonesia. Pendidikan selain sebagai sarana tranfer ilmu pengetahuan, sosial budaya juga merupakan sarana untuk mewariskan ideologi bangsa kepada generasi selanjutnya. Pendidikan suatu bangsa akan secara otomatis mengikuti ideologi suatu bangsa yang dianutnya. Pancasila adalah dasar dan ideologi bangsa Indonesia yang mempunyai fungsi dalam hidup dan kehidupan bangsa dan negara Indonesia. Filsafat adalah berfikir secara mendalam dan sungguh-sungguh untuk mencari kebenaran, filsafat pendidikan adalah pemikiran yang mendalam tentang pendidikan berdasarkan filsafat, apabila kita hubungkan fungsi

Pancasila dengan sistem pendidikan ditinjau dari filsafat pendidikan, bahwa Pancasila pandangan hidup bangsa yang menjiwai dalam kehidupan sehari-hari. Karena itu, sistem pendidikan nasional Indonesia wajar apabila dijiwai, didasari, dan mencerminkan identitas Pancasila. Cita dan karsa bangsa Indonesia diusahakan secara melembaga dalam sistem pendidikan nasioanl yang bertumpu dan dijiwai oleh suatu keyakinan, pandangan hidup dan folosofi tertentu. Inilah dasar pikiran mengapa filsafat pendidikan Pancasila merupakan tuntutan nasional dan sistem filsafat pendidikan Pancasila adalah sub sistem dari sistem negara 
Pancasila. Dengan memperhatikan fungsi pendidikan dalam membangun potensi bangsa, khususnya dalam melestarikan kebudayaan dan kepribadian bangsa yang ada pada akhirnya menentukan eksistensi dan martabat bangsa, maka sistem pendidikan nasional dan filsafat pendidikan pancasila seyogyanya terbina secara optimal supaya terjamin tegaknya martabat dan kepribadian bangsa. Filsafat pendidikan Pancasila merupakan aspek rohaniah atau spiritual sistem pendidikan nasional, tiada sistem pendidikan nasional tanpa filsafat pendidikan.

\section{Filsafat Pancasila dalam Membangun Bangsa Berkarakter}

Pengertian karakter menurut Pusat Bahasa Depdiknas adalah "bawaan, hati, jiwa, kepribadian, budi pekerti, perilaku, personalitas, sifat, tabiat, temperamen, watak". Adapun berkarakter adalah berkepribadian, berperilaku, bersifat, bertabiat, dan berwatak". Menurut Musfiroh (2008), karakter mengacu kepada serangkaian sikap (attitudes), perilaku (behaviors), motivasi (motivations), dan keterampilan (skills). Karakter berasal dari bahasa Yunani yang berarti "to mark" atau menandai dan memfokuskan bagaimana mengaplikasikan nilai kebaikan dalam bentuk tindakan atau tingkah laku, sehingga orang yang tidak jujur, kejam, rakus dan perilaku jelek lainnya dikatakan orang berkarakter jelek. Sebaliknya, orang yang perilakunya sesuai dengan kaidah moral disebut dengan berkarakter mulia. Dari pengertian di atas dapat dimaknai bahwa pendidikan karakter merupakan suatu proses penanaman perilaku yang didasarkan pada budi pekerti yang baik sesuai dengan kepribadian luhur bangsa Indonesia yang didasarkan pada nilai-nilai Pancasila.

Menurut Ramli (2003), pendidikan karakter memiliki esensi dan makna yang sama dengan pendidikan moral dan pendidikan akhlak. Tujuannya adalah membentuk pribadi anak, supaya menjadi manusia yang baik, warga masyarakat, dan warga negara yang baik. Adapun kriteria manusia yang baik, warga masyarakat yang baik, dan warga negara yang baik bagi suatu masyarakat atau bangsa, secara umum adalah nilai-nilai sosial tertentu yang banyak dipengaruhi oleh budaya masyarakat dan bangsanya. Oleh karena itu, hakikat dari pendidikan karakter dalam konteks pendidikan di Indonesia adalah pedidikan nilai, yakni pendidikan nilai-nilai luhur yang bersumber dari budaya bangsa Indonesia sendiri, dalam rangka membina kepribadian generasi muda. Pancasila sebagai sistem filsafat bisa dilihat dari pendekatan ontologis, epistemologis, maupun aksiologis.

Diktat "Filsafat Pancasila" (Danumihardja, 2011) menyebutkan secara ontologis berdasarkan pada pemikiran tentang negara, bangsa, masyarakat, dan manusia. Secara epistemologis berdasarkan sebagai suatu pengetahuan intern struktur logis dan konsisten implementasinya. Secara aksiologis bedasarkan pada yang terkandung di dalamnya, hirarki dan struktur nilai, di dalamnya konsep etika yang terkandung. Dasar ontologis Pancasila sebagai sistem filsafat bisa diinterpretasikan bahwa adanya negara perlu dukungan warga negara. Kualitas negara sangat bergantung pada kualitas warga negara. Kualitas warga negara sangat erat berkaitan dengan pendidikan. Hubungan ini juga menjadi timbal-balik karena landasan pendidikan haruslah mengacu pada landasan negara. Esensi landasan negara harus benarbenar memperkuat landasan pendidikan untuk mencapai tujuan bersama adanya keserasian hubungan antara negara dengan warga negara.

Demokrasi Pancasila menegaskan pengakuan atas harkat dan martabat manusia sebagai makhluk masyarakat, Negara, dan masyarakat bangsa (Arbi, 1998). Orientasi hidup kita adalah hidup kemanusiaan yang mempunyai ciri-ciri tertentu. Ciri-ciri kemanusiaan yang kelihatan dari Pancasila ialah integral, etis, dan religius (Poeposwardoyo, 1989). Filsafat pendidikan Pancasila mengimplikasikan ciri-ciri tersebut, yaitu sebagai berikut.

a. Integral Kemanusiaan yang diajarkan oleh Pancasila adalah kemanusiaan yang integral, yakni mengakui manusia seutuhnya. Manusia diakui sebagai suatu keutuhan jiwa dan raga, keutuhan antara manusia sebagai individu dan makhluk sosial. Kedua hal itu sebenarnya adalah dua sisi dari satu realitas tentang manusia. Hakekat manusia yang seperti inilah yang merupakan hakekat subjek didik.

b. Etis Pancasila merupakan kualifikasi etis. Pancasila mengakui keunikan subjektivitas manusia, ini berarti menjungjung tinggi kebebasan, namun tidak dari segalanya seperti liberalisme. Kebebasan yang dimaksud adalah kebebasan yang bertanggung jawab.

c. Religius Sila pertama pancasila menegaskan bahwa religius melekat pada hakikat manusia, maka pandangan kemanusiaan Pancasila adalah paham kemanusiaan religius. Religius menunjukan kecendrungan dasar dan potensi itu. Pancasila mengakui Tuhan sebagai pencipta serta sumber keberadaan dan menghargai religius dalam masyarakat sebagai yang bermakna. Kebebasan agama adalah satu hak yang paling asasi diantara hak-hak asasi 
manusia, karena kebebasan agama itu langsung bersumber kepada martabat manusia sebagai makhluk ciptaan Tuhan. Hak kebebasan agama bukan pemberian negara atau pemberian perorangan atau golongan. Agama dan kepercayaan terhadap Tuhan Yang Maha Esa sendiri tidak memaksa setiap manusia untuk memeluk agama tertentu.

Berdasarkan beberapa penjelasan di atas, dapat dimaknai bahwa pendidkan karakter di Indonesia merupakan hasil dari penerapan nilai-nilai yang terkandung dalam Pancasila. Pancasila adalah falsafah yang merupakan pedoman berperilaku bagi bangsa Indonesia yang sesuai dengan kultur kita bangsa Indonesia yang memiliki adat ketimuran. Pendidikan karakter memang seharusnya diambil dari nilai-nilai yang terkandung dalam Pancasila. Agar tercipta manusia Indonesia yang cerdas, berperilaku baik, mampu hidup secara individu dan sosial, memenuhi hak dan kewajiban sebagai warga negara yang baik serta beriman dan bertaqwa kepada Tuhan Yang Maha Esa. Semuanya telah mencakup filsafat pendidikan Pancasila yang mempunyai ciri yaitu integral, etis dan reigius. Seorang pendidik haruslah sadar akan pentingnya pendidikan karakter. Salah satu cara untuk menerapkan pendidikan karakter adalah dengan melaksanakan nilai-nilai Pancasila. Di bawah ini ada beberapa poin yang harus dilakukan oleh pendidik dalam melaksanakan nilai-nilai Pancasila.

a. Harus memahami nilai-nilai Pancasila tersebut.

b. Menjadikan Pancasila sebagai aturan hukum dalam kehidupan.

c. Memberikan contoh pelaksanaan nilai-nilai pendidikan kepada peserta didik dengan baik.

Dengan melaksanakan tiga point di atas, diharapkan cita-cita bangsa yang ingin melaksanakan pendidikan berkarakter sesuai falsafah pancasila akan terwujud. Karena bagaimanapun juga perkembangan ilmu pengetahuan dan teknologi terus berkembang setiap waktu sehingga tidak mungkin rasanya menghambat perkembangan itu. Untuk itu, satu-satunya jalan dalam menerapkan pendidikan berkarakter adalah dengan melaksanakan poin-poin di atas.

\section{Simpulan dan Saran}

Pancasila merupakan dasar pandangan hidup rakyat Indonesia yang di dalamnya memuat lima dasar yang isinya merupakan jati diri bangsa Indonesia. Sila-sila dalam Pancasila menggambarkan tentang pedoman hidup berbangsa dan bernegara bagi manusia Indonesia seluruhnya dan seutuhnya. Pancasila juga merupakan sebuah filsafat karena pancasila merupakan acuan intelektual kognitif bagi cara berpikir bangsa yang dalam usaha-usaha keilmuan dapat terbangun ke dalam sistem filsafat yang kredibel. Pendidikan suatu bangsa akan secara otomatis mengikuti ideologi suatu bangsa yang dianutnya. Pancasila adalah dasar dan ideologi bangsa Indonesia yang mempunyai fungsi dalam hidup dan kehidupan bangsa dan negara Indonesia. Filsafat adalah berfikir secara mendalam dan sungguh-sungguh untuk mencari kebenaran. Filsafat pendidikan adalah pemikiran yang mendalam tentang pendidikan berdasarkan filsafat. Apabila kita hubungkan fungsi Pancasila dengan sistem pendidikan ditinjau dari filsafat pendidikan, maka Pancasila merupakan pandangan hidup bangsa yang menjiwai dalam kehidupan sehari-hari. Karena itu, sistem pendidikan nasional Indonesia wajar apabila dijiwai, didasari dan mencerminkan identitas Pancasila. Pancasila adalah falsafah yang merupakan pedoman berperilaku bagi bangsa Indonesia yang sesuai dengan kultur bangsa Indonesia. Pendidikan karakter memang seharusnya diambil dari nilai-nilai yang terkandung dalam Pancasila. Agar tercipta manusia Indonesia yang cerdas, berperilaku baik, mampu hidup secara individu dan sosial, memenuhi hak dan kewajiban sebagai warga negara yang baik serta beriman dan bertaqwa kepada Tuhan Yang Maha Esa. Semuanya telah mencakup filsafat pendidikan Pancasila yang mempunyai ciri, yaitu integral, etis dan reigius.

\section{Daftar Pustaka}

Arifin, H.M. 1993. IImu Pendidikan Islam: Suatu Tinjauan Teori dan Praktis Berdasarkan Pendekatan Interdisipliner. Jakarta: Bina Aksara.

Darmodiharjo, Darji. 1996, Pokok-pokok Filsafat Hukum. Jakarta: Gramedia Pustaka Utama.

Jumali, dkk. 2004. Landasan Pendidikan. Surakarta: Muhammadiyah University Press. 
Kaelan. 2005. Filsafat Pancasila sebagai Filasfat Bangsa Negara Indonesia. Makalah pada Kursus Calon Dosen Pendidikan Kewarganegaraan, Jakarta.

Noor Syam, Moh. 1986. Filsafat Pendidikan dan Dasar Filsafat Kependidikan Pancasila. Surabaya: Usaha Nasional.

Poespowardoyo, Soeryanto. 1989. Filsafat Pancasila. Jakarta: Gramedia.

Rapar, J.H. 1988. Filsafat Politik Aristoteles. Jakarta: Rajawali.

Sutrisno, Slamet. 2006. Filsafat dan Ideologi Pancasila. Yogyakarta: Andi. 